\title{
Evaluation of the Nutrient Content and Sensory Properties of Spiced Ogi (Gruel) Produced From Different Cereal Blends
}

\author{
Eke- Ejiofor J* \\ Department of Food Science and Technology, Rivers State University, Nkpolu Oroworukwo. P.M.B.5080, Port Harcourt.
}

Received: October 16, 2018; Accepted: November 27, 2018; Published: December 5, 2018

*Corresponding author: Eke-Ejiofor J, Department of Food Science and Technology, Rivers State University, Nkpolu Oroworukwo. P.M.B. 5080, Port Harcourt. Nigeria; Email: joyekee@yahoo.co.uk

\begin{abstract}
The nutrient composition and sensory properties of spiced ogi produced form blends of maize (yellow), millets and guinea corn were investigated. Functional properties of the samples showed that water absorption capacity ranged between $3.25-3.66 \%$, solubility 3.15 $6.54 \%$, swelling power between $70.50 \%-74.50 \%$, relative bulk density $0.2 \mathrm{~g} / \mathrm{ml}-0.41 \mathrm{~g} / \mathrm{ml}$ and the least gelation concentration between $2.00-6.00 \%$. There were significant differences $(\mathrm{P} \leq 0.05)$ in all the functional properties. The Chemical composition of ogi blends showed that moisture content ranged $7.45 \%-10.15 \%$, ash between $0.22-0.3 \%$, while fat content ranged $2.89 \%-5.9 \%$. Protein content increased in all the samples which ranged from $5.73 \%-7.43 \%$ while carbohydrate ranged $77.00 \%-81.46 \%$. Amylose and amylopectin fraction of starch ranged between $28.51 \%-31.73 \%$ and $68.27 \%-71.57 \%$, with sugar and starch content ranging between $2.39 \%-4.18 \%$ and $52.59 \%-77.80 \%$, respectively. All chemical parameters showed significant differences $(P \leq 0.05)$. Pasting properties decreased with an increase in the substitution of millet and guinea corn for maize showing a significant difference $(\mathrm{P} \leq 0.05)$ in all the pasting parameters.
\end{abstract}

Keywords: composite starch; functional; chemical; pasting sensory properties; cereals; spices;

\section{Introduction}

Ogi a local gruel is one of the popular indigenous fermented food in Nigeria. It is usually made from Maize cereal (Zea mays) singly or in combinations with guinea corn (Sorghum bicolour) and Millet (Pennisetum glaucum). The Ogi gruel is very smooth in texture and has a sour taste reminiscent of that of yoghurt [1].

Cereal based fermented foods constitute a major source of dietary nutrients all over the world, although cereals are deficient in some basic components (essential amino acids) as fermentation may be the most simple and economical way of improving their nutritional value, sensory properties, and functional qualities.

Conventionally, Ogi production for daily domestic family use required single cereal such as maize. The high level of its utilization for food and animal feed has resulted in overdependence in terms of cost. Recent trend has moved towards the use of combination of cereals in addition to different locally available spices, with the aim of improving nutritional value of the product as well as product taste.

Ogi is one of the common family breakfast gruel and most often used as weaning food in West Africa, as it is the first semisolid and the most popular weaning food used by African mothers in general and Nigerians in particular, for feeding of infants, due to its availability and affordability. The method of processing ogi locally is a contributory factor to its loss in nutrients. The use of multiple cereals and spices may enhance the nutrients of the composite Ogi, as well as diversify the use of other cereals and local spices. Maize, guinea corn and millet are essential raw material for gruel production as they are economically good due to their wide availability, high carbohydrate content and nutritional values.

The use of processed Ogi for family and infant use may pose some nutritional challenge if not complemented since maize is deficient the amino acid lysine.

The objectives of the work are; to prepare Ogi (gruel) from blend of locally available cereals (maize, millet and guinea corn), and to determine the effect of composite blends on the nutritional composition and sensory qualities of the gruel.

\section{Materials and Methods}

Yellow maize (Zea mays), millet (pennisetum glaucum), guinea corn (Sorghum bicolor) were purchase from mile 1 market and other ingredients such as Uda (Tylopia aethiopica), clove (Syzygium aromaticum) and ginger (Zingiber officinale) were purchased from fruit garden markets D/Line, Port Harcourt Rivers State, Nigeria.

\section{Preparation of Ogi Starch}

Cereal grains maize, millet and guinea corn were sorted, cleaned and soaked in water for $48 \mathrm{hrs}$. The soaked grains were then wet milled. The cereal paste was washed and sieved using muslin cloth. The sieved starch was allowed to sediment. The sediment was decanted and dried in an air circulating oven at $50^{\circ} \mathrm{C}$ for 24 hours. The dried starch was then milled to powder. 


\section{Preparation of Spiced Starch Blends}

The cereal were prepared singly and also in blends with graded levels of maize, millet guinea corn and species (ginger; Uda and clove) in different quantities. The reasons for the variation in quantity and ratio of spices to cereals were based on monitory value as prepared and used locally.

\section{Functional Properties}

Relative bulk density of cereals starch blends were determined by the method of [2], while swelling power and solubility was determined according to the method of [3]. Dispersibility was determined by the method of [4]. Water absorption capacity and least gelation concentration were determined by the methods of $[5,6]$ respectively.

\section{Chemical Analysis}

The moisture content of the samples was determined using moisture analyzer AMB-ML-50 at $130^{\circ} \mathrm{C}$. Ash, fiber, fat (soxhlet extraction) and crude protein contents (micro-kjeldhal method) were determined according to the method described by [7] The amylose content of starch extracted from the samples were determined using the iodine calometric method reported by [8], while amylopectin was calculated by difference. Starch and sugar were determined by the method of [9].

\section{Pasting properties of Starch}

Pasting properties of the different starches were analysed using the rapid visco analyzer (RVA) model 3C, Newport scientific PTY Ltd (1998) as reported by [9] .

\section{Sensory Evaluation}

An independent sensory evaluation was done using twenty Semi-trained panelists from the Department of Food Science and Technology, Rivers State University, who were neither sick nor allergic to cereals or spices. Twenty coded samples of spiced Ogi (gruel) were presented to each panelist. The parameters determined, were color, aroma, taste, texture, consistency, mouth feel and general acceptability using a nine point hedonic scale as reported by [10]. Samples were served in a white disposable plates and water was provided for mouth rinsing between samples.

\section{Statistical Analysis}

Result were statistically analyzed using analysis of variance, (ANOVA) level of significance within means was calculated using the least significant difference and standard deviation.

\begin{tabular}{|c|c|c|c|c|c|c|c|}
\hline \multicolumn{2}{|c|}{ Table 1: Recipe for the production of different Ogi Blends } \\
\hline S/NO & Cereals Ratio & Maize(g) & Millet(g) & Guinea corn & Ginger & Uda & clove \\
\hline A & $100 \%$ & 2000 & - & - & 40 & 4 & 3 \\
\hline B & $100 \%$ & - & 2000 & - & 40 & 4 \\
\hline C & $100 \%$ & - & - & 2000 & 40 & 4 & 3 \\
\hline D & $80.10: 10$ & 1600 & 200 & 200 & 40 & 4 & 3 \\
\hline E & $70: 15: 15$ & 1400 & 300 & 300 & 40 & 4 & 3 \\
\hline F & $60: 20: 20$ & 1200 & 400 & 400 & 40 & 4 & 3 \\
\hline G & $50: 25: 25$ & 1000 & 500 & 500 & 40 & 4 \\
\hline H & $40: 30: 30$ & 800 & 600 & 600 & 40 & 4 \\
\hline I & $20: 35: 35$ & 600 & 700 & 700 & 40 & 3 \\
\hline J & $20: 40: 40$ & 400 & 800 & 800 & 40 & 4 \\
\hline
\end{tabular}

\section{Results and Discussion}

\section{Functional Properties of Spiced Ogi Produced From Cereal Blends}

Table 1: shows the functional properties of spiced ogi produced from cereal blends.

Water absorption capacity ranged from $3.25 \%$ to $3.66 \%$. The results obtained from the present study showed that there were no significant differences $(\mathrm{P}>0.05)$ in water absorption capacity. This result falls within the range reported by [11] with a value of $3.45 \%-4.12 \%$. Water absorption capacity is an important functional property required in food formulations especially those involving dough handling [12].

Solubility values ranged from $3.15 \%$ to $6.54 \%$ with sample F (60\%maize+20\%millet+20\%guinea corn) as the highest and sample B (100\%millet) as the lowest. Solubility of spiced ogi ranging from $3.15 \%-6.54 \%$ showed that there were significant differences $(\mathrm{P}<0.050$ in the solubility of starch samples. The solubility of sample F (6.54\%) was significantly higher than sample B (3.15\%), I (3.53\%), and J (3.73\%). These results were lower than the findings of [11] who reported a solubility ranging between 8.76 - 9.92\% for Sorghum- wheat composite flour. 
Table 1: Functional properties of spiced Ogi produced from different cereal blends

\begin{tabular}{|c|c|c|c|c|c|c|}
\hline & $\begin{array}{c}\text { Water Absorption } \\
\text { Capacity (\%) }\end{array}$ & Solubility (\%) & $\begin{array}{c}\text { Swelling power } \\
\text { (\%) }\end{array}$ & $\begin{array}{c}\text { Dispersibility } \\
\text { (\%) }\end{array}$ & $\begin{array}{c}\text { Relative bulk density } \\
\text { (g) }\end{array}$ & $\begin{array}{c}\text { Least Gelation } \\
\text { Concentration }\end{array}$ \\
\hline A & $3.37 \pm 0.46^{\mathrm{c}}$ & $5.59 \pm 0.00^{\mathrm{b}}$ & $8.84 \pm 0.32^{\mathrm{c}}$ & $73.00 \pm 0.50^{\mathrm{b}}$ & $0.33 \pm 0.03^{\mathrm{c}}$ & $6.00 \pm 00^{\mathrm{a}}$ \\
\hline B & $3.25 \pm 0.14^{\mathrm{e}}$ & $3.15 \pm 0.15^{\mathrm{d}}$ & $10.01 \pm 0.51^{\mathrm{a}}$ & $72.00 \pm 0.50^{\mathrm{c}}$ & $0.26 \pm 0.04^{\mathrm{d}}$ & $4.00 \pm 00^{\mathrm{b}}$ \\
\hline C & $3.52 \pm 0.01^{\mathrm{b}}$ & $5.53 \pm 2.16^{\mathrm{b}}$ & $6.86 \pm 1.28^{\mathrm{e}}$ & $72.50 \pm 0.50^{\mathrm{c}}$ & $0.24 \pm 0.00^{\mathrm{d}}$ & $4.00 \pm 00^{\mathrm{b}}$ \\
\hline D & $3.37 \pm 0.01^{\mathrm{c}}$ & $4.33 \pm 0.45^{\mathrm{c}}$ & $8.64 \pm 0.23^{\mathrm{d}}$ & $74.50 \pm 0.50^{\mathrm{a}}$ & $0.37 \pm 0.02^{\mathrm{b}}$ & $6.00 \pm 00^{\mathrm{a}}$ \\
\hline E & $3.35 \pm 0.02^{\mathrm{b}}$ & $6.17 \pm 0.50^{\mathrm{a}}$ & $9.52 \pm 0.50^{\mathrm{b}}$ & $74.50 \pm 0.50^{\mathrm{a}}$ & $0.41 \pm 0.50^{\mathrm{a}}$ & $4.00 \pm 00^{\mathrm{b}}$ \\
\hline F & $3.42 \pm 0.17^{\mathrm{c}}$ & $6.54 \pm 0.35^{\mathrm{a}}$ & $9.78 \pm 0.12^{\mathrm{a}}$ & $71.00 \pm 0.50^{\mathrm{d}}$ & $0.33 \pm 0.00^{\mathrm{c}}$ & $6.00 \pm 00^{\mathrm{a}}$ \\
\hline G & $3.54 \pm 0.03^{\mathrm{b}}$ & $3.59 \pm 0.00^{\mathrm{d}}$ & $7.52 \pm 1.31^{\mathrm{d}}$ & $71.50 \pm 0.50^{\mathrm{d}}$ & $0.37 \pm 0.00^{\mathrm{b}}$ & $6.00 \pm 00^{\mathrm{a}}$ \\
\hline H & $3.66 \pm 0.04^{\mathrm{a}}$ & $4.28 \pm 0.31^{\mathrm{c}}$ & $6.70 \pm 0.39^{\mathrm{e}}$ & $70.50 \pm 0.50^{\mathrm{e}}$ & $0.33 \pm 0.03^{\mathrm{c}}$ & $2.00 \pm 00^{\mathrm{c}}$ \\
\hline I & $3.41 \pm 0.01^{\mathrm{c}}$ & $3.53 \pm 0.75^{\mathrm{d}}$ & $7.11 \pm 0.29^{\mathrm{e}}$ & $73.50 \pm 0.50^{\mathrm{b}}$ & $0.31 \pm 0.00^{\mathrm{c}}$ & $2.00 \pm 00^{\mathrm{c}}$ \\
\hline J & $3.52 \pm 0.02^{\mathrm{b}}$ & $3.73 \pm 0.15^{\mathrm{d}}$ & $6.49 \pm 0.45^{\mathrm{e}}$ & $71.50 \pm 0.50^{\mathrm{d}}$ & $0.30 \pm 0.00^{\mathrm{c}}$ & $2.00 \pm 00^{\mathrm{c}}$ \\
\hline
\end{tabular}

Values are mean of duplicate determination \pm standard deviation means having different superscript in the same column are significantly different $(\mathrm{P}<0.05)$.

Key:

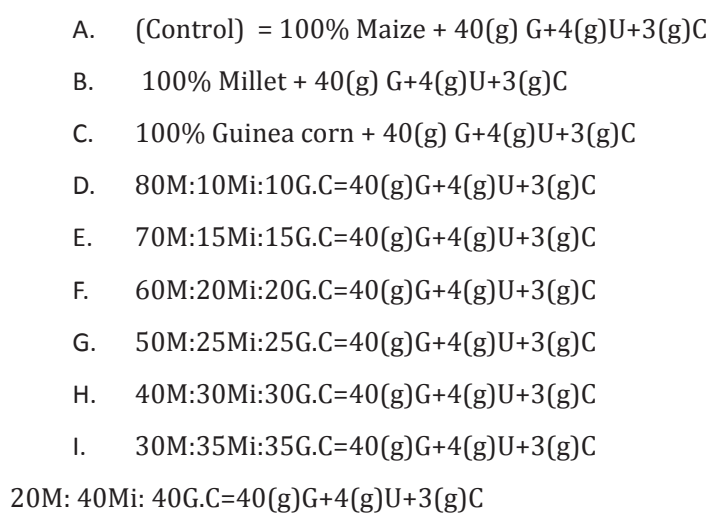

Swelling power ranged from $6.49 \%$ to $10.01 \%$ with sample B as the highest and sample J as the lowest. Swelling power of spiced ogi showed that the samples differed significantly $(\mathrm{P}<0.05)$. The result of the present study is in agreement with the findings of Adebowale et al., (2012) who reported a value of $9.87-10.21$ for sorghum - wheat flour composite. Swelling power determine the extent to which a starch sample increases in volume when soaked in water in relation to its initial volume.

Dispersibility ranged from $70.50 \%$ to $74.50 \%$ with sample D and $\mathrm{E}$ having the highest value and sample $\mathrm{H}$ as the lowest. The dispersibility result showed no significant difference $(\mathrm{P}>0.05)$.

Relative bulk density ranged from $0.26 \mathrm{~g} / \mathrm{ml}$ to $0.4 \mathrm{~g} / \mathrm{ml}$. The result of the present study showed that report is in agreement with the findings of [13] who reported a value of $0.5 \mathrm{~g} / \mathrm{ml}-0.6 \mathrm{~g} /$ $\mathrm{ml}$.

Least gelation concentration ranging from $2.00 \%-6.00 \%$ with samples A (control), D, F, G having the highest percentage least of gelation.

M = Maize
Mi = Millet
G.C=Guinea corn
G=Ginger
U=Uda
C=Clove

\section{Chemical Composition of Spiced Ogi Produced From Cereal Blends}

Table 2: Shows the chemical composition of spiced ogi produced from cereal blends.

Moisture content ranged from $7.45 \%$ to $10.15 \%$ with sample $\mathrm{C}$ as the highest and sample $\mathrm{J}$ as the lowest. Moisture content ranging from $7.45 \%-10.15 \%$ is in agreement with the findings of Sylvester et al.,(2016) with a value of $9.07 \%-8.90 \%$ in ogi with spices, and also within the finding of [14] who reported a moisture content of $6.54-11.20 \%$ for spiced ogi produced from maize in an earlier study. Furthermore [14] stated that low moisture content in dry products is an indication of better shelf life and storability.

Ash content ranging from $0.22 \%-0.35 \%$, with sample $\mathrm{A}$ (control) as the lowest and sample $\mathrm{G}$ as the highest falls within the range reported by [14] with a value of $0.49 \%-1.69 \%$. The present study showed that ash content increased with the addition of spices and also falls within the range (0.19-0.49\%) earlier reported by [15] for spiced ogi from maize. The result of the present study is also lower than that reported by [14]. The 


\begin{tabular}{|c|c|c|c|c|c|c|c|c|c|c|}
\hline Code & Moisture \% & Ash \% & Fat $\%$ & Protein \% & Fibre $\%$ & СHO \% & Sugar \% & Starch \% & Amylose \% & Amylopectin \% \\
\hline A & $9.15 \pm 0.05^{b}$ & $0.22 \pm 0.02^{\mathrm{d}}$ & $5.27 \pm 0.31^{\mathrm{c}}$ & $5.73 \pm 0.00^{\mathrm{d}}$ & $0.18 \pm 0.01^{\mathrm{e}}$ & $79.77 \pm 0.08^{\mathrm{c}}$ & $4.01 \pm 0.01^{\mathrm{b}}$ & $70.32 \pm 0.38^{\mathrm{d}}$ & $30.95 \pm 0.07^{\mathrm{c}}$ & $69.06 \pm 0.07$ \\
\hline B & $9.40 \pm 0.20^{\mathrm{b}}$ & $0.29 \pm 0.00^{\mathrm{b}}$ & $5.38 \pm 0.20^{\mathrm{b}}$ & $7.43 \pm 0.00^{\mathrm{a}}$ & $0.20 \pm 0.01^{\mathrm{d}}$ & $77.00 \pm 0.71^{\mathrm{f}}$ & $2.39 \pm 0.03^{g}$ & $52.59 \pm 0.31^{\mathrm{h}}$ & $29.92 \pm 0.08^{\mathrm{d}}$ & $70.08 \pm 0.08^{\mathrm{d}}$ \\
\hline $\mathrm{C}$ & $10.15 \pm 0.55^{\mathrm{a}}$ & $0.25 \pm 0.01^{\mathrm{c}}$ & $3.88 \pm 0.10^{\mathrm{d}}$ & $7.38 \pm 0.00^{\mathrm{b}}$ & $0.21 \pm 0.01^{\mathrm{c}}$ & $77.64 \pm 0.95^{\mathrm{f}}$ & $3.38 \pm 0.04^{\mathrm{de}}$ & $82.31 \pm 0.51^{\mathrm{a}}$ & $28.43 \pm 0.00^{\mathrm{f}}$ & $71.57 \pm 0.00^{\mathrm{a}}$ \\
\hline $\mathrm{D}$ & $9.50 \pm 0.50^{\mathrm{b}}$ & $0.25 \pm 0.05^{c}$ & $4.49 \pm 0.09^{d}$ & $5.69 \pm 0.00^{\mathrm{d}}$ & $0.20 \pm 0.01^{\mathrm{d}}$ & $79.88 \pm 0.45^{\mathrm{b}}$ & $3.12 \pm 0.01^{\mathrm{f}}$ & $57.42 \pm 0.27^{\mathrm{g}}$ & $29.02 \pm 0.04^{\mathrm{e}}$ & $70.98 \pm 0.04^{c}$ \\
\hline $\mathrm{E}$ & $8.95 \pm 0.05^{c}$ & $0.28 \pm 0.01^{b}$ & $4.78 \pm 0.00^{c}$ & $7.42 \pm 0.00^{b}$ & $0.35 \pm 0.01^{b}$ & $78.23 \pm 0.07^{\mathrm{e}}$ & $3.41 \pm 0.01^{\mathrm{d}}$ & $63.76 \pm 0.05^{\mathrm{e}}$ & $31.73 \pm 0.08^{\mathrm{a}}$ & $68.27 \pm 0.08^{f}$ \\
\hline $\mathrm{F}$ & $7.95 \pm 0.05^{f}$ & $0.29 \pm 0.01^{b}$ & $5.38 \pm 0.42^{\mathrm{b}}$ & $6.51 \pm 0.00^{c}$ & $0.18 \pm 0.01^{\mathrm{e}}$ & $79.69 \pm 0.47^{f}$ & $3.76 \pm 0.00^{c}$ & $57.83 \pm 0.11^{\mathrm{g}}$ & $29.14 \pm 0.08^{\mathrm{e}}$ & $70.87 \pm 0.07^{\mathrm{c}}$ \\
\hline G & $8.80 \pm 0.10^{\mathrm{d}}$ & $0.35 \pm 0.05^{\mathrm{a}}$ & $5.38 \pm 0.19^{b}$ & $7.39 \pm 0.00^{\mathrm{b}}$ & $0.48 \pm 0.02^{\mathrm{a}}$ & $77.61 \pm 0.25^{\mathrm{f}}$ & $4.09 \pm 0.12^{\mathrm{ab}}$ & $61.28 \pm 0.11^{\mathrm{f}}$ & $28.58 \pm 0.00^{\mathrm{f}}$ & $71.42 \pm 0.00^{\mathrm{ab}}$ \\
\hline $\mathrm{H}$ & $8.35 \pm 0.05^{\mathrm{e}}$ & $0.26 \pm 0.00^{c}$ & $5.98 \pm 0.61^{\mathrm{a}}$ & $5.73 \pm 0.00^{\mathrm{d}}$ & $0.45 \pm 0.01^{\mathrm{b}}$ & $79.23 \pm 0.65^{\mathrm{d}}$ & $3.36 \pm 0.04^{\text {de }}$ & $71.30 \pm 0.20^{\mathrm{c}}$ & $29.73 \pm 0.12^{\mathrm{d}}$ & $70.28 \pm 0.12^{\mathrm{d}}$ \\
\hline I & $9.00 \pm 0.00^{\mathrm{c}}$ & $0.25 \pm 0.00^{c}$ & $4.99 \pm 0.20^{c}$ & $6.51 \pm 0.00^{c}$ & $0.50 \pm 0.01^{\mathrm{a}}$ & $78.76 \pm 0.15^{d}$ & $3.14 \pm 0.03^{f}$ & $71.83 \pm 0.21^{\mathrm{c}}$ & $31.50 \pm 0.07^{\mathrm{ab}}$ & $68.51 \pm 0.07^{\mathrm{f}}$ \\
\hline $\mathrm{J}$ & $7.45 \pm 0.05^{f}$ & $0.30 \pm 0.00^{\mathrm{b}}$ & $2.89 \pm 0.10^{\mathrm{e}}$ & $7.42 \pm 0.00^{\mathrm{b}}$ & $0.49 \pm 0.00^{\mathrm{a}}$ & $81.46 \pm 0.16^{\mathrm{a}}$ & $4.18 \pm 0.08^{\mathrm{a}}$ & $77.80 \pm 0.37^{\mathrm{b}}$ & $28.51 \pm 0.07^{\mathrm{f}}$ & $71.50 \pm 0.07^{\mathrm{ab}}$ \\
\hline \multicolumn{11}{|c|}{$\begin{array}{l}\text { Values are mean of duplicate determination } \pm \text { standard deviation Means having different superscript in the same column are significantly different }(\mathrm{P}<0.05) \text {. } \\
\text { Key: }\end{array}$} \\
\hline A. & \multicolumn{5}{|c|}{ (Control) $100 \%$ Maize $+40(\mathrm{~g}) \mathrm{G}+4(\mathrm{~g}) \mathrm{U}+3(\mathrm{~g}) \mathrm{C}$} & \multicolumn{5}{|l|}{ ÿ M = Maize } \\
\hline B. & \multicolumn{5}{|c|}{$100 \%$ Millet $+40(\mathrm{~g}) \mathrm{G}+4(\mathrm{~g}) \mathrm{U}+3(\mathrm{~g}) \mathrm{C}$} & \multicolumn{5}{|l|}{$. \ddot{y} \mathrm{Mi}=$ Millet } \\
\hline C. & \multicolumn{5}{|c|}{$100 \%$ Guinea corn $+40(\mathrm{~g}) \mathrm{G}+4(\mathrm{~g}) \mathrm{U}+3(\mathrm{~g}) \mathrm{C}$} & \multicolumn{5}{|c|}{$\ddot{~ y ̈ ~ G . C=G u i n e a ~ c o r n ~}$} \\
\hline D. & \multicolumn{5}{|c|}{ 80M:10Mi:10G.C $=40(\mathrm{~g}) \mathrm{G}+4(\mathrm{~g}) \mathrm{U}+3(\mathrm{~g}) \mathrm{C}$} & \multicolumn{5}{|l|}{$\ddot{y} \mathrm{G}=$ Ginger } \\
\hline E. & \multicolumn{5}{|c|}{ 70M:15Mi:15G.C=40(g)G+4(g)U+3(g)C } & \multicolumn{5}{|l|}{$\ddot{y} U=U d a$} \\
\hline F. & \multicolumn{5}{|c|}{ 60M:20Mi:20G.C $=40(\mathrm{~g}) \mathrm{G}+4(\mathrm{~g}) \mathrm{U}+3(\mathrm{~g}) \mathrm{C}$} & \multicolumn{5}{|l|}{ ÿ C=Clove } \\
\hline G. & \multicolumn{5}{|c|}{ 50M:25Mi:25G.C $=40(\mathrm{~g}) \mathrm{G}+4(\mathrm{~g}) \mathrm{U}+3(\mathrm{~g}) \mathrm{C}$} & & & & & \\
\hline H. & \multicolumn{5}{|c|}{ 40M:30Mi:30G.C $=40(\mathrm{~g}) \mathrm{G}+4(\mathrm{~g}) \mathrm{U}+3(\mathrm{~g}) \mathrm{C}$} & & & & & \\
\hline I. & \multicolumn{5}{|c|}{ 30M:35Mi:35G.C $=40(\mathrm{~g}) \mathrm{G}+4(\mathrm{~g}) \mathrm{U}+3(\mathrm{~g}) \mathrm{C}$} & & & & & \\
\hline $\mathrm{J}$. & \multicolumn{5}{|c|}{ 20M:40Mi:40G.C $=40(\mathrm{~g}) \mathrm{G}+4(\mathrm{~g}) \mathrm{U}+3(\mathrm{~g}) \mathrm{C}$} & & & & & \\
\hline
\end{tabular}

ash content of a food sample gives an indication of the mineral element in the food. It indicates the composition of inorganic constituent after organic materials and moisture have been removed by drying.

Fat content ranged from $2.89 \%-5.98 \%$ which is lower than the finding of [16] who had a value of $5.82-7.47 \%$. The fat content in the present study increased by $51.67 \%$ in sample $\mathrm{H}$ which had $60 \%$ of its maize component substituted with $30 \%$ each of millet and guinea corn.

Protein content ranged from $5.69 \%$ to $7.43 \%$ with sample D $(80 \%$ maize $+20 \%$ millet $+20 \%$ guinea corn +3 spices $)$ as the lowest and sample B (100\% millet+3spices) as the highest. The results obtained were higher than the findings of with a value of $4.11 \%-5.22 \%$, but lower than the findings of Eke-Ejiofor and Beleya (2017) with maximum protein of $8.01 \%$ for spiced maize ogi.

Results showed that individual cereals had higher protein values as seen in samples $\mathrm{B}(100 \%$ millet $)$ and $\mathrm{C}(100 \%$ guinea corn) as well as the $\mathrm{H}$, which had the least ratio of maize.

Fibre ranged from $0.18 \%$ to $0.50 \%$ with sample A (control) as the least and sample I as the highest. Crude fiber content in the present study is close to that reported $0.19-0.59 \%$ by [14] for spiced maize ogi.

Carbohydrate ranged from $77.00 \%$ to $81.46 \%$ with sample $\mathrm{B}$ as the lowest and J as the highest. Carbohydrate content in this report is higher than the findings of with a range of 73.90
- 78.79\%. The carbohydrate content of the samples gives an indication that the gruel will be a good source of calorie

The sugar content ranged from $2.39 \%$ to $4.18 \%$ with sample $\mathrm{B}$ as the lowest and sample $\mathrm{J}$ as the highest. The sugar content of the samples showed that sample B (100\%millet) as the least and sample J (20\%maize, $40 \%$ millet, $40 \%$ guinea corn) as the highest. This result is higher than the findings of [14] who reported a value of $0.21-0.42$ for spiced maize ogi. Result also showed a positive relationship between carbohydrate content and sugar.

Starch content ranged between $52.59 \%$ to $82.31 \%$ with sample B (100\%Millet) as the lowest and sample C (100\%Guinea corn) as the highest. This study showed that the lower the maize component of the blends the closer the starch content to the control. The mixed cereal blends also showed better starch out content when compared with the findings of [14], who reported starch content ranging between $39.04-45.59 \%$ for maize spiced ogi. Starch is the major component in the samples.

Amylose content ranged from $28.43-31.73 \%$ with sample C as the lowest and sample $\mathrm{E}$ as the highest. The higher the amylose content, the lower is the swelling power of the starch and the smaller is the gel strength for the same starch concentration. However a smaller swelling power due to high amylose content can be counteracted by a larger granule size. Of the two components of starch, amylose has the most useful function as a hydrocolloid, while Amylopectin ranged from 68.27 - 71.57\% with sample $\mathrm{E}$ as the lowest and sample $\mathrm{C}$ as the highest. Amylose 
and amylopectin form the major constituents of starches and their amount vary based on the type of plant species and variety. The results obtained in the present study is in agreements with the findings of who reported a value of $30.00-37.50 \%$ and $62.5-$ $70.00 \%$ for amylose and amylopectin respectively, but lower than the findings of who reported higher amylose content of 32.83 to $37.82 \%$ for maize spiced ogi. The low values of amylose and amylopectin in the present study may be as a result of the effect of the composite blends on the total component as well as the presence of the spices.

\section{Pasting properties of spiced ogi produced from different cereal blends.}

Table 3: Shows the pasting properties of spiced ogi produced from different cereal blends.
Peak viscosity ranged from 223.17 - 350.42RVU with sample A (control-100\%maize) having the highest value and sample $\mathrm{H}$ (40M: 30M: 30G) as the lowest. The results obtained showed that peak viscosity decreased with addition of other cereal blends to maize. The samples differed significantly meaning that an increase in guinea corn and millet, and the reduction in maize content showed a decrease in the peak viscosity. The difference in the peak viscosity is due to their differences in water absorption [19] the importance of peak viscosity in weaning food is that it signifies the ability of the formulation to gel or not.

The trough ranged between 123.58 - 186.08RVU with sample I having the highest value and sample $\mathrm{F}$ as the least.

\begin{tabular}{|c|c|c|c|c|c|c|c|c|}
\hline & Sample code & PV & Trough & BD & FV & SB & Pasting Time & Pasting Temp. \\
\hline A & Maize control & $350.42^{\mathrm{a}}$ & $157.42^{\mathrm{g}}$ & $193.00^{\mathrm{a}}$ & $273.67^{d}$ & $116.25^{d}$ & $4.53^{\mathrm{h}}$ & $75.85^{\mathrm{h}}$ \\
\hline B & Millet & $327.33^{d}$ & $160.33^{d}$ & $167.00^{\mathrm{d}}$ & $228.00^{\mathrm{b}}$ & $117.67^{b}$ & $4.87^{\mathrm{d}}$ & $79.15^{\mathrm{a}}$ \\
\hline $\mathrm{C}$ & Guinea corn & $276.58^{g}$ & $161.58^{\mathrm{b}}$ & $115.00^{\mathrm{g}}$ & $268.67^{\mathrm{f}}$ & $107.08^{g}$ & $4.67^{\mathrm{f}}$ & $78.35^{c}$ \\
\hline D & $80: 10: 10$ & $349.67^{b}$ & $160.42^{c}$ & $188.67^{b}$ & $270.92^{\mathrm{e}}$ & $110.50^{\mathrm{e}}$ & $4.53^{\mathrm{h}}$ & $76.75^{\mathrm{f}}$ \\
\hline E & $70: 15: 15$ & $347.67^{c}$ & $159.17^{\mathrm{e}}$ & $188.50^{c}$ & $264.83^{\mathrm{g}}$ & $105.67^{\mathrm{h}}$ & $4.67^{g}$ & $77.55^{e}$ \\
\hline $\mathrm{F}$ & $60: 20: 20$ & $277.83^{\mathrm{f}}$ & $123.58^{\mathrm{j}}$ & $154.25^{\mathrm{e}}$ & $221.17^{j}$ & $97.58^{\mathrm{i}}$ & $4.73^{\mathrm{e}}$ & $76.70^{\mathrm{g}}$ \\
\hline G & $50: 25: 25$ & $273.33^{\mathrm{h}}$ & $159.00^{\mathrm{f}}$ & $114.33^{\mathrm{h}}$ & $276.17^{c}$ & $117.17^{c}$ & $5.13^{\mathrm{b}}$ & $78.40^{\mathrm{b}}$ \\
\hline $\mathrm{H}$ & $40: 30: 30$ & $223.17^{\mathrm{k}}$ & $142.42^{\mathrm{i}}$ & $80.75^{\mathrm{g}}$ & $234.58^{\mathrm{i}}$ & $92.17^{j}$ & $5.20^{\mathrm{a}}$ & $79.15^{\mathrm{a}}$ \\
\hline I & $30: 35: 35$ & $315.25^{\mathrm{e}}$ & $186.08^{\mathrm{a}}$ & $129.17^{\mathrm{f}}$ & $323.50^{\mathrm{a}}$ & $137.42^{\mathrm{a}}$ & $5.07^{\mathrm{c}}$ & $78.30^{\mathrm{d}}$ \\
\hline $\mathrm{J}$ & $20: 40: 40$ & $255.75^{\mathrm{i}}$ & $147.50^{\mathrm{h}}$ & $108.25^{i}$ & $256.00^{\mathrm{h}}$ & $108.50^{\mathrm{f}}$ & $5.13^{\mathrm{b}}$ & $79.15^{\mathrm{a}}$ \\
\hline \multicolumn{9}{|c|}{ Means having different superscript in the same column are significantly different $(\mathrm{P}<0.05)$. } \\
\hline \multicolumn{9}{|c|}{ Key: PV = Peak viscosity } \\
\hline \multicolumn{9}{|c|}{$\mathrm{BD}=$ Breakdown viscosity } \\
\hline \multicolumn{9}{|c|}{$\mathrm{FV}=$ Final viscosity } \\
\hline \multicolumn{9}{|c|}{$\mathrm{SB}=$ Setback viscosity } \\
\hline A. & \multicolumn{3}{|c|}{$($ Control $)=100 \%$ Maize $+40(\mathrm{~g}) \mathrm{G}+4(\mathrm{~g}) \mathrm{U}+3(\mathrm{~g}) \mathrm{C}$} & \multicolumn{2}{|c|}{ M = Maize } & & & \\
\hline B. & \multicolumn{3}{|c|}{$100 \%$ Millet $+40(\mathrm{~g}) \mathrm{G}+4(\mathrm{~g}) \mathrm{U}+3(\mathrm{~g}) \mathrm{C}$} & \multicolumn{2}{|c|}{$\mathrm{Mi}=$ Millet } & & & \\
\hline C. & \multicolumn{3}{|c|}{$100 \%$ Guinea corn $+40(\mathrm{~g}) \mathrm{G}+4(\mathrm{~g}) \mathrm{U}+3(\mathrm{~g}) \mathrm{C}$} & \multicolumn{2}{|c|}{ G.C=Guinea corn } & & & \\
\hline D. & \multicolumn{3}{|c|}{ 80M:10Mi:10G.C $=40(\mathrm{~g}) \mathrm{G}+4(\mathrm{~g}) \mathrm{U}+3(\mathrm{~g}) \mathrm{C}$} & \multicolumn{2}{|c|}{$\mathrm{G}=$ Ginger } & & & \\
\hline E. & \multicolumn{3}{|c|}{ 70M:15Mi:15G.C=40(g)G+4(g)U+3(g)C } & \multicolumn{2}{|c|}{$\mathrm{U}=\mathrm{Uda}$} & & & \\
\hline F. & \multicolumn{3}{|c|}{ 60M:20Mi:20G.C=40(g)G+4(g)U+3(g)C } & \multicolumn{2}{|c|}{$\mathrm{C}=$ Clove } & & & \\
\hline G. & \multicolumn{5}{|c|}{ 50M:25Mi:25G.C=40(g)G+4(g)U+3(g)C } & & & \\
\hline H. & \multicolumn{5}{|c|}{ 40M:30Mi:30G.C=40(g)G+4(g)U+3(g)C } & & & \\
\hline I. & \multicolumn{5}{|c|}{ 30M:35Mi:35G.C=40(g)G+4(g)U+3(g)C } & & & \\
\hline J. & \multicolumn{5}{|c|}{ 20M:40Mi:40G.C=40(g)G+4(g)U+3(g)C } & & & \\
\hline
\end{tabular}

Breakdown ranged from 114.33 to 193.00 RVU The breakdown viscosity of the sample ranged between 108.25 193.00RVU, with sample A (control) as the highest and sample $\mathrm{J}(20.40 .40)$ as the least respectively (P 0.05 ). The breakdown viscosity is a measure of the degree of paste stability or starch granules in disintegration during heating [21]. Therefore, the samples with low breakdown viscosity will have a more stable paste during heating than others with high breakdown viscosity.

Final viscosity of the spiced gruel ranged from 221.17 323.30RVU with sample I (30:35:35) as the highest and sample F $(60: 20: 20)$ as the least. The results showed an increase in the final viscosity with the samples of $(100 \%)$ maize, millet and guinea corn respectively when compared with the blends except 
sample I, which had the highest final viscosity than the others. The result of this study is higher than the findings of [23] that reported a value of $87.2-141.3 \mathrm{RVU}$.

The set back ranged from 97.58 - 137.42RVU with sample $\mathrm{H}$ (40:30:30) as the least and sample I (30:35:35) as the highest. The value obtained showed that there was significant difference $(\mathrm{P} \leq 0.05)$ amongst the samples. The higher the setback viscosity, the lower the retro gradation of the flour paste during cooling and the lower the stalling rate of the product made from the flour.

The pasting time ranged from $4.53 \mathrm{~min}-5.20 \mathrm{~min}$. The pasting time temperature showed an indication of minimum temperature required from cooking the samples. Pasting time, peak time which is a measure of the cooking time ranged between $4.53-5.20$ with sample $\mathrm{H}$ as the highest and sample $\mathrm{D}$ as the least. There was significant difference amongst the samples except samples A and $D$, as well as $G$ and J which did not differ significantly. While pasting temperature ranged from $75.85^{\circ} \mathrm{C}$ to $79.15^{\circ} \mathrm{C}$ with sample $\mathrm{B}, \mathrm{H}$ and $\mathrm{J}$ having the highest value and sample a having the lowest. Sample B, H and J showed no significant difference between them but differs significantly from the other samples.

\section{Sensory evaluation of spiced ogi produced from cereal blends.}

Table 4: Shows the sensory evaluation of spiced ogi produced from cereal blends. Color ranged from 4.40 to 7.60 with sample $C$ (100\% guinea corn) as the highest and sample B (100\% millet), as the lowest. This is expected as millet grain has a natural dark color. The aroma ranged from 3.95 to 6.65 with sample D as the most preferred, and sample B as the least preferred. Taste, texture, monuthfeel and overall acceptability ranged from 4.00 $6.45,5.60-6.80,5.42-7.15$ and $5.20-7.30$ respectively with the parameters showing no significant difference ( $\mathrm{p} \geq 0.05)$ amongst the samples.

Table 4: Mean sensory score of spiced Ogi produced from different cereal blends

\begin{tabular}{|c|c|c|c|c|c|c|c|}
\hline & Colour & Aroma & Taste & Texture & Consistency & Mouth feel & Overall acceptability \\
\hline A & $6.40 \pm 2.14^{\mathrm{a}}$ & $6.30 \pm 2.03^{\mathrm{a}}$ & $6.40 \pm 2.28^{\mathrm{a}}$ & $6.30 \pm 2.18^{\mathrm{a}}$ & $6.15 \pm 2.58^{\mathrm{a}}$ & $6.42 \pm 1.57^{\mathrm{a}}$ & $6.85 \pm 1.81^{\mathrm{a}}$ \\
\hline B & $4.40 \pm 2.02^{\mathrm{b}}$ & $3.95 \pm 2.09^{\mathrm{d}}$ & $4.00 \pm 2.03^{\mathrm{c}}$ & $5.00 \pm 2.21^{\mathrm{a}}$ & $5.60 \pm 2.11^{\mathrm{a}}$ & $5.85 \pm 1.89^{\mathrm{a}}$ & $5.20 \pm 1.82^{\mathrm{a}}$ \\
\hline C & $7.60 \pm 1.19^{\mathrm{a}}$ & $6.45 \pm 1.47^{\mathrm{a}}$ & $6.25 \pm 1.53^{\mathrm{a}}$ & $6.25 \pm 1.77^{\mathrm{a}}$ & $6.50 \pm 1.43^{\mathrm{a}}$ & $6.25 \pm 1.52^{\mathrm{a}}$ & $7.30 \pm 1.17^{\mathrm{a}}$ \\
\hline D & $6.00 \pm 2.27^{\mathrm{a}}$ & $6.65 \pm 1.27^{\mathrm{a}}$ & $6.45 \pm 1.55^{\mathrm{a}}$ & $6.60 \pm 1.54^{\mathrm{a}}$ & $6.70 \pm 1.87^{\mathrm{a}}$ & $6.65 \pm 1.27^{\mathrm{a}}$ & $6.95 \pm 1.09^{\mathrm{a}}$ \\
\hline E & $6.34 \pm 1.67^{\mathrm{a}}$ & $6.30 \pm 1.67^{\mathrm{b}}$ & $6.40 \pm 1.54^{\mathrm{a}}$ & $7.10 \pm 1.07^{\mathrm{a}}$ & $6.80 \pm 1.77^{\mathrm{a}}$ & $7.00 \pm 1.56^{\mathrm{a}}$ & $7.05 \pm 1.64^{\mathrm{a}}$ \\
\hline F & $6.25 \pm 1.52^{\mathrm{a}}$ & $6.40 \pm 2.14^{\mathrm{a}}$ & $6.35 \pm 2.16^{\mathrm{a}}$ & $7.00 \pm 1.38^{\mathrm{a}}$ & $6.65 \pm 1.79^{\mathrm{a}}$ & $7.15 \pm 1.97^{\mathrm{a}}$ & $7.00 \pm 1.97^{\mathrm{a}}$ \\
\hline H & $6.00 \pm 2.27^{\mathrm{a}}$ & $5.05 \pm 2.50^{\mathrm{c}}$ & $4.95 \pm 2.24^{\mathrm{b}}$ & $5.95 \pm 2.21^{\mathrm{a}}$ & $6.55 \pm 1.73^{\mathrm{a}}$ & $5.42 \pm 2.19^{\mathrm{a}}$ & $5.90 \pm 1.89^{\mathrm{a}}$ \\
\hline J & $7.20 \pm 1.17^{\mathrm{a}}$ & $5.80 \pm 1.67^{\mathrm{c}}$ & $5.60 \pm 1.73^{\mathrm{a}}$ & $6.20 \pm 1.74^{\mathrm{a}}$ & $5.90 \pm 2.17^{\mathrm{a}}$ & $6.42 \pm 2.06^{\mathrm{a}}$ & $6.35 \pm 1.49^{\mathrm{a}}$ \\
\hline V & $7.00 \pm 1.97^{\mathrm{a}}$ & $5.50 \pm 1.85^{\mathrm{c}}$ & $5.65 \pm 2.25^{\mathrm{a}}$ & $5.70 \pm 2.05^{\mathrm{a}}$ & $6.15 \pm 2.06^{\mathrm{a}}$ & $5.70 \pm 1.59^{\mathrm{a}}$ & $5.90 \pm 1.55^{\mathrm{a}}$ \\
\hline
\end{tabular}

Values are mean of duplicate determination \pm standard deviation Means having different superscript in the same column are significantly different $(\mathrm{P}<0.05)$.

Key:

$\begin{array}{ll}\text { A. } & \text { (Control) }=100 \% \text { Maize }+40(\mathrm{~g}) \mathrm{G}+4(\mathrm{~g}) \mathrm{U}+3(\mathrm{~g}) \mathrm{C} \\ \text { B. } & 100 \% \text { Millet }+40(\mathrm{~g}) \mathrm{G}+4(\mathrm{~g}) \mathrm{U}+3(\mathrm{~g}) \mathrm{C} \\ \text { C. } & 100 \% \text { Guinea corn }+40(\mathrm{~g}) \mathrm{G}+4(\mathrm{~g}) \mathrm{U}+3(\mathrm{~g}) \mathrm{C} \\ \text { D. } & \text { 80M:10Mi:10G.C }=40(\mathrm{~g}) \mathrm{G}+4(\mathrm{~g}) \mathrm{U}+3(\mathrm{~g}) \mathrm{C} \\ \text { E. } & 70 \mathrm{M}: 15 \mathrm{Mi}: 15 \mathrm{G} . \mathrm{C}=40(\mathrm{~g}) \mathrm{G}+4(\mathrm{~g}) \mathrm{U}+3(\mathrm{~g}) \mathrm{C} \\ \text { F. } & 60 \mathrm{M}: 20 \mathrm{Mi}: 20 \mathrm{G} \cdot \mathrm{C}=40(\mathrm{~g}) \mathrm{G}+4(\mathrm{~g}) \mathrm{U}+3(\mathrm{~g}) \mathrm{C} \\ \text { G. } & \text { 50M:25Mi:25G.C }=40(\mathrm{~g}) \mathrm{G}+4(\mathrm{~g}) \mathrm{U}+3(\mathrm{~g}) \mathrm{C} \\ \text { H. } & \text { 40M:30Mi:30G.C }=40(\mathrm{~g}) \mathrm{G}+4(\mathrm{~g}) \mathrm{U}+3(\mathrm{~g}) \mathrm{C} \\ \text { I. } & \text { 30M:35Mi:35G.C }=40(\mathrm{~g}) \mathrm{G}+4(\mathrm{~g}) \mathrm{U}+3(\mathrm{~g}) \mathrm{C} \\ \text { J. } & \text { 20M:40Mi:40G.C }=40(\mathrm{~g}) \mathrm{G}+4(\mathrm{~g}) \mathrm{U}+3(\mathrm{~g}) \mathrm{C}\end{array}$

$\ddot{y} \mathrm{M}=$ Maize
ÿ Mi = Millet
$\ddot{y} \mathrm{G} . \mathrm{C}=$ Guinea corn
$\ddot{\mathrm{y}} \mathrm{G}=$ Ginger
$\ddot{\mathrm{y}} \mathrm{U}=$ Uda
$\ddot{\mathrm{y}} \mathrm{C}=$ Clove




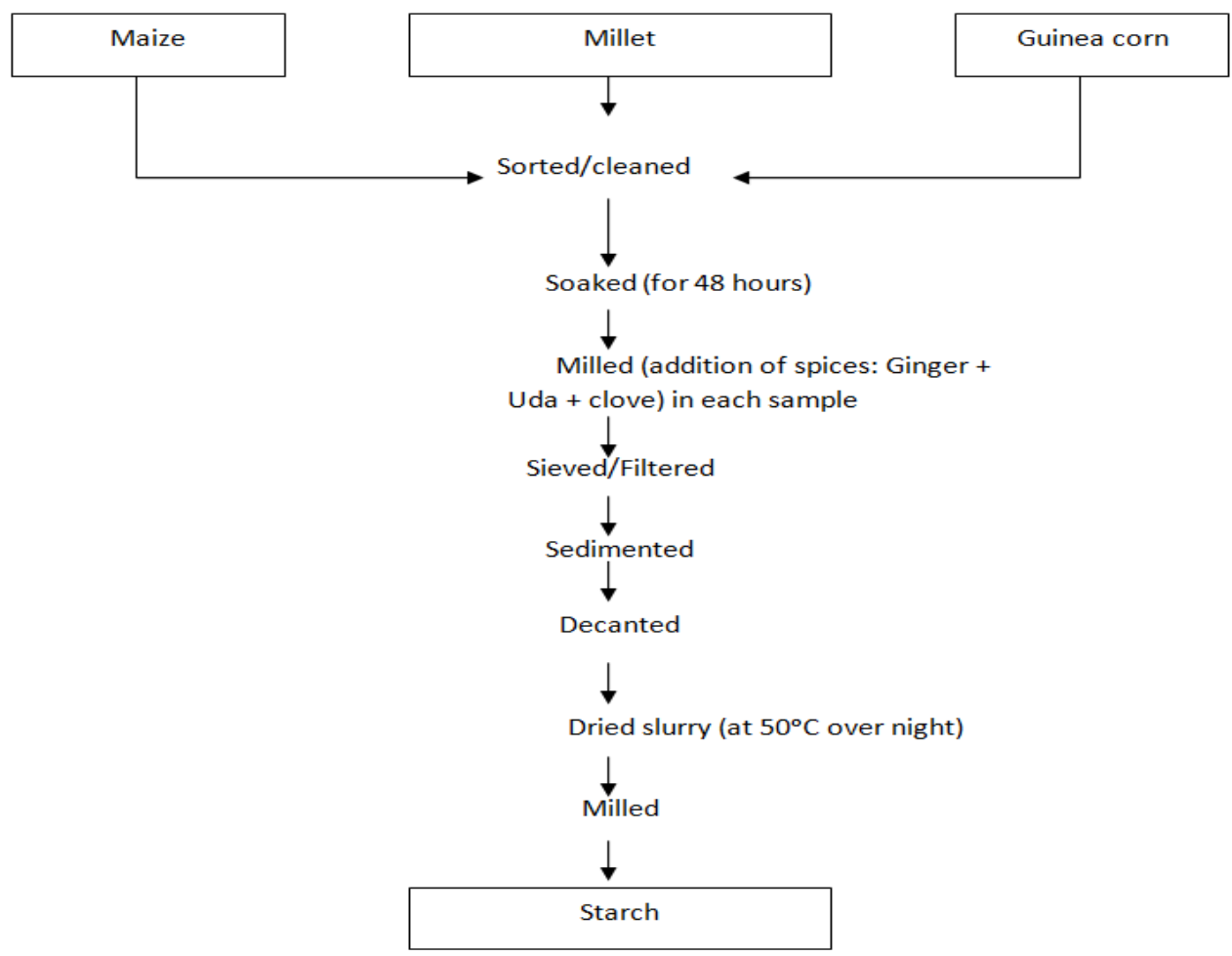

Figure 1: flow chart for the production of spiced Ogi

Source: Eke-Ejiofor and Beleya (2017)

\section{Conclusion}

The study has shown that addition of spices (Ginger, uda and clove) increased nutritional value of ogi. The intended blends (maize, millet and guinea corn) are use for ogi production because the trio combination make ogi a more nutritious meal for infant. Corn is mainly a good source of carbohydrate, millet and guinea corn offers some proteins, vitamins and minerals that are very essential for the growth of infant.

\section{References}

1. Banigo EOI and Muller HG. Carboxylic acid pattern in Ogi fermentation. Journal of Science Food Agriculture. 1972;23(1):101-111.

2. Narayana K, Narasinga Rao MS. Effect of partial proteolysis on the functional properties of winged pea (Psophocapus tetragonolobus) flour. Journal of Food Science. 1982;49:944-947.

3. Takashi S, Sieb PA. Paste and gel properties of prime corn and wheat starches with and without native lipids. Cereal Chemistry 1988;65(6):474.

4. Kulkarni KD, Kulkarni DN, Ingle UM. Sorghum malt-based weaning formulations, preparation, functional properties and nutritive values. Food and Nutrition Bulletin. 1991;13(4):322-327.

5. Onwulatu CI, Smith DW, Konstance RP, Holsinger VH. Physical properties of extruded products as affected by cheese whey - Journal of Science. 1998;63:814-818.
6. Sathe SK, Deshpande SS, Salunkhe DK. Functional properties of winged bean (Phaseolus vulgaris) proteins: Emulsion, foaming, viscosity and gelation properties. Journal of Food Science. 1982;46(1):71-75.

7. AOAC. Official methods of analysis (15th ed.) Washington DC: Association of official analytic chemists. 1990.

8. Zakpaa HD, AI-Hassun A, Adubotar J. An investigation into the feasibility of production and characterization of starch from (Apunli) plantain (Giant harn) grown in Ghana. African Journal of Food Science. 2010;4(9):571-577.

9. Eke J. (2006). Chemical, functional and Pasting Properties of Starch and Tapioca produced from selected hybrid Cassava(Manihot esculenta crantz) cultivars. Unpublished Ph.D thesis.

10. Onwuka GI. Food Analysis and Instrumentation theory and practice. 2005;95-96.

11. Adebowale AA, Adegoke MT, Sanni SA, Adegunwa MO and Fetuga GO. Functional properties and biscuit making potentials of sorghum wheat flour composite. American Journal of Food Technology. 2012;7(6):372-379.

12. Lorenz K, Collins F. Quinoa, starch physicochemical properties and functional characteristics, Starch. 1980;42:81-86.

13. Fasasi OS, Adegemi IA, Fagbenro OA. Functional and pasting characteristics of fermented maize and nile tilapia (Oreochromics niloticus) flour Diet. Pakistan Journal of Nutrition. 2007;6(4):304-309.

14. Eke-Ejiofor J, Beleya, EA. Chemical, Mineral, Pasting and Sensory properties of Spiced Ogi (Gruel). American Journal of Food Science and Technology. 2017;5(5):204-209. 
15. Farinde EO. Chemical and sensory properties of sieved and unsieved fortified ogi. Natural Science. 2015;13(1):49-53.

16. Edet UO, Ebana RGB, Okoro CU, Ekanemesang UM, Ikon GM and Ntukidem NW, et al. Composition of corn meal (ogi) assisted with lactobacillus spices. Journal of Advances in Microbiology. 2017;2(1):16.

17. Ajanaku KO, Ajani O, Siyanbola TO, Akinsiku AA, Ajanaku CO and Oluwole O. Dietary Fortification of Sorghum-Ogi using crayfish (paranephrophs planifrons) as Supplements Infancy. 2013;15:22246088.

18. Felix Narku Engmann. Physico-chemical and pasting characteristics of flour and starch from Aerial yam. American Journal of Food Science and Nutrition. 2016;3(1):1-7.

19. Ragace S, Abdel-Aal EM. Pasting properties of starch and protein in selected cereals and quality of their food products. Food Chemistry. 2006;95:9-18.
20. Mazurs EG, Schoch TJ, Kite FE. The roles of amylose and amylopectin in the gelation and retrogradation of starch. Carbohydratre Research. 1957;135:271-281.

21. Dengate HW. Swelling, pasting and gelling of wheat starch. In: pomeranz Y. (Ed). Advances in Cereal Science and Technology. America Association of Cereal Chemists (AACC), St Paul. 1984;49-82.

22. Farhar IA, Oguntona T, Neale JR. Characterization of starches from West African yams. Journal of Science Food and Agriculture. 1999;79(15):2105-2112.

23. Fasoyiro SB, Arowora KA. Chemical, pasting and sensory properties of whole fermented maize (ogi) fortified with pigeon pea flour. Food Research International. 2010;43(4):931-1222.

24. Adeyemi IA, Idowu MA. Evaluation of pre-gelatinized maize flour in the development of "Maissai" a baked product. Nigerian Food Journal. 1990;8:63-73. 